\title{
USING ANALYTICAL SERVICES AT THE NATIONAL WATER QUALITY LABORATORY
}

By Linda K. Pratt

U.S. GEOLOGICAL SURVEY

Open-File Report 94-26

Denver, Colorado

1994

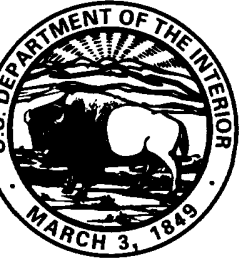




\section{U.S. DEPARTMENT OF THE INTERIOR \\ BRUCE BABBITT, Secretary \\ U.S. GEOLOGICAL SURVEY}

Robert M. Hirsch, Acting Director

Chief, National Water Quality Laboratory

U.S. Geological Survey

Box 25046, Mail Stop 407

Federal Center

Denver, CO 80225
U.S. Geological Survey

Books and Open-File Reports Section

Box 25425, Mail Stop 517

Federal Center

Denver, CO 80225-0425 


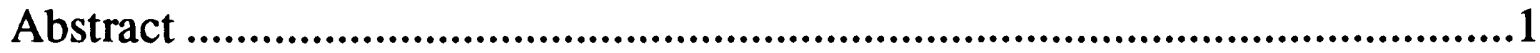

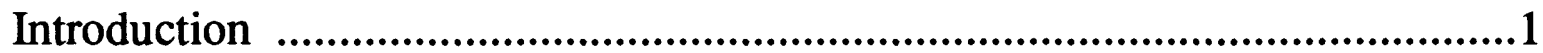

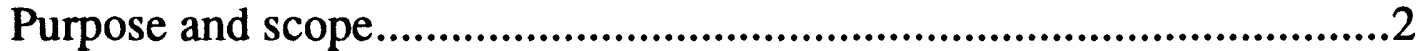

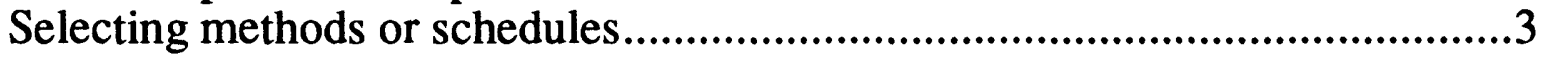

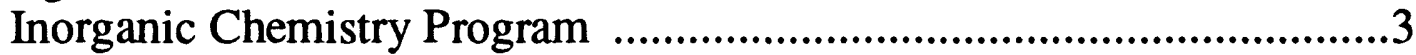

Organic Chemistry Program …...........................................................5

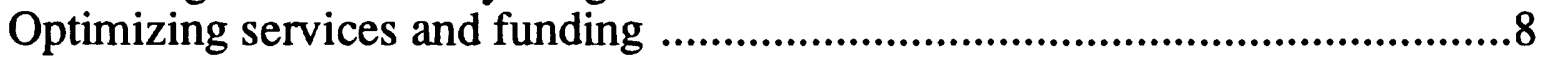

Obtaining approval for regulatory testing ......................................................9

Approved methods and suggestions for

National Pollution Discharge Elimination System Program .......................11

Safe Drinking Water Act................................................................................12

How to avoid unwanted swapping of test procedures

and ensure delivery of acceptable data ...................................................14

Contacting National Water Quality Laboratory staff .....................................14

References cited ......................................................................................15

\section{TABLES}

Page

Table 1. Method precision at reporting limit of four instrumental techniques for selected metals ...........................3

2. Summary of organic schedules..............................................7

3. U.S. Geological Survey and U.S. Environmental

Protection Agency methods 10

4. Methods for which the National Water Quality Laboratory has drinking-water certification in Region 8, U.S. Environmental Protection Agency 


\section{ABBREVIATED WATER-QUALITY UNITS AND ACRONYMS}

$\begin{array}{ll}\text { mg/L } & \text { milligram per liter } \\ \mu \mathrm{g} / \mathrm{L} & \text { microgram per liter } \\ \mu S / \mathrm{cm} & \text { microsiemens per centimeter at 25 degrees Celsius } \\ \text { AAS } & \text { Atomic Absorption Spectrophotometry } \\ \text { ASR } & \text { Analytical Services Request Form } \\ \text { BNA } & \text { Base Neutral Acid } \\ \text { BQA } & \text { Branch of Quality Assurance } \\ \text { DODEC } & \text { Department of Defense Environmental Contamination } \\ \text { GC/MS } & \text { Gas Chromatography/Mass Spectrometry } \\ \text { GF-AAS } & \text { Graphite Furnace Atomic Absorption Spectrophotometry } \\ \text { ICP } & \text { Inductively Coupled Plasma } \\ \text { ICP-MS } & \text { Inductively Coupled Plasma-Mass Spectrometry } \\ \text { NAWQA } & \text { National Water-Quality Assessment Program } \\ \text { NPDES } & \text { National Pollution Discharge Elimination System } \\ \text { NWQL } & \text { National Water Quality Laboratory } \\ \text { SCH } & \text { Schedule } \\ \text { SPN } & \text { Schedules, Parameter, and Network Program } \\ \text { USEPA } & \text { U.S. Environmental Protection Agency } \\ \text { USGS } & \text { U.S. Geological Survey } \\ \text { VOC } & \text { Volatile Organic Compound }\end{array}$

Degrees Celsius $\left({ }^{\circ} \mathrm{C}\right)$ may be converted to degrees Fahrenheit $\left({ }^{\circ} \mathrm{F}\right)$ by using the following equation:

$$
{ }^{\circ} \mathrm{F}=9 / 5\left({ }^{\circ} \mathrm{C}\right)+32
$$




\title{
USING ANALYTICAL SERVICES AT THE NATIONAL WATER QUALITY LABORATORY
}

\author{
By Linda K. Pratt
}

\begin{abstract}
The National Water Quality Laboratory (NWQL) offers a variety of analytical methods for the determination of constituents in water, bed sediment, and tissue samples. As technology has advanced, many new methods have been introduced, but not always incorporated into plans and schedules developed in the districts. The strengths and weaknesses of many different techniques are discussed and evaluated to promote a broader understanding of the methods available at the NWQL. Method detection limits, precision, and costs also are discussed, as well as possible applications for the methods. To aid in project planning, several tables have been developed that list the suggested or approved method for certain determinations, particularly those being requested to satisfy cooperator or U.S. Environmental Protection Agency regulatory requirements.
\end{abstract}

\section{INTRODUCTION}

As the National Water Quality Laboratory (NWQL) has grown, it has added methods, developed expertise in new areas, and extended the scope of services available. As always, with growth, there has also been change, and this open-file report is intended to assist district personnel in interpreting some of the changes that have taken place at the NWQL during the past few years. Many new methods have been developed that can provide lower detection limits or improved precision, and several new organic methods have been introduced that are more efficient and more cost-effective (Watterson and Kashuba, 1993) than previously used methods.

Technological advances in analytical instrumentation and increasingly sophisticated data requirements from the U.S. Geological Survey (USGS) and cooperators have combined to make method selection a complex and often confusing process. To clarify the process, this guide has been developed as a source of introductory information to assist users of NWQL services in selecting analytical services that best meet their needs.

The NWQL has introduced several new methods for regulatory and reconnaissance testing, and some of these methods are discussed herein. Also, for those who need information on U.S. Environmental Protection Agency (USEPA) equivalency, a table has been developed (see table 3) that lists the USEPA method and the comparable USGS method.

It is hoped that this report will be a useful tool for all customers requesting laboratory services from the NWQL. Please contact the NWQL anytime method selection or data interpretation is difficult or uncertain. 


\section{Purpose and Scope}

This report is intended to serve as a user's guide to some of the services available at the NWQL. In many instances, inorganic constituents may be determined by a variety of methods. There are also several new organic methods that have been developed recently to provide comprehensive testing for organic compounds. This report describes some of the more commonly used analytical methods and provides the district user with information on how to select the proper method for a given project. This report also provides a brief explanation of the applicability of some of the organic methods that are currently (1994) available. Comparison tables of both inorganic and organic methods have been developed to aid in the selection of methods.

Because the NWQL offers a wide variety of analytical services, not all constituents and methods are mentioned herein. This report focuses primarily on those methods that are frequently requested, or on methods that are occasionally used in place of requested methods or confused with other methods. This report is intended to serve as a general guide to assist district personnel in maximizing the services received from the NWQL; it should be used as a supplemental reference to the NWQL Services Catalog (Watterson and Kashuba, 1993), or to assist in the interpretation of information contained in the Schedules, Parameter, and Network (SPN) Program. For more specific information, the reader is encouraged to call the NWQL directly. 


\title{
SELECTING METHODS OR SCHEDULES
}

\author{
Inorganic Chemistry Program
}

The Inorganic Chemistry Program offers analyses for trace metals, major cations and anions, and nutrients in water, bed sediment, and tissue samples by a variety of analytical techniques. The applicability and usefulness of each method will vary depending on a project's data-quality objectives and the type of water that is being tested. While each of the following options might have different strengths and weaknesses, methods should be selected on the basis of project requirements as related to analytical needs and available funding. For additional information on any of the methods used in the Inorganic Chemistry Program, contact the program chief.

\section{AAS--Atomic Absorption Spectrophotometry}

This technique is used to determine one analyte at a time and is considered the least subject to interferences for determining many metals. The sample is atomized in a flame and the ground state atoms absorb radiation emitted from a light source of corresponding wavelength. In general, reporting limits for AAS determinations will be considerably higher than those for Inductively Coupled Plasma (ICP), but if a limited number of constituents is required, the AAS analysis may cost less than the ICP analysis. Since AAS instruments are capable of withstanding high concentrations of dissolved solids or salts, this technique is commonly used for brines, acid-mine drainages, and samples with specific conductance greater than $2,000 \mu \mathrm{S} / \mathrm{cm}$. (See table 1 for comparison of techniques.)

\section{Table 1.--Method precision at reporting limit of four instrumental techniques for selected metals}

[AAS, Atomic Absorption Spectrophotometry; GF-AAS, Graphite Fumace Atomic Absorption Spectrophotometry ; ICP, Inductively Coupled Plasma; ICPMS, Inductively Coupled Plasma-Mass Spectrometry; N/A, Not Applicable; R.L., Reporting Limit; \%RSD, Percent Relative Standard Deviation]

\begin{tabular}{|c|c|c|c|c|c|c|c|c|}
\hline \multirow[b]{2}{*}{ Analyte } & \multicolumn{2}{|c|}{ AAS } & \multicolumn{2}{|c|}{ GF-AAS } & \multicolumn{2}{|c|}{ ICP } & \multicolumn{2}{|c|}{ ICP-MS } \\
\hline & R.L. & $\%$ RSD & R.L. & $\%$ RSD & $\overline{\text { R.L }}$ & $\%$ RSD & R.L & \% RSD ${ }^{1}$ \\
\hline Cadmium & 10 & 100 & 1 & 28 & 1 & 172 & 1 & 5 \\
\hline Chromium & N/A & & .5 & 120 & 5 & 62 & 1 & 3 \\
\hline Cobalt & 50 & 150 & 1 & 38 & 3 & 46 & 1 & 2 \\
\hline Copper & 10 & 200 & 1 & 35 & 10 & 21 & 1 & 2 \\
\hline Lead & 100 & 100 & 1 & 128 & 10 & 50 & 1 & 6 \\
\hline Molybdenum & 1 & 230 & N/A & & 10 & 40 & 1 & 7 \\
\hline Nickel & 100 & 100 & 1 & 65 & 10 & 44 & 1 & 6 \\
\hline Silver & N/A & & 1 & 24 & 1 & 104 & 1 & 2 \\
\hline Zinc & 10 & 36 & N/A & & 3 & 320 & 1 & 4 \\
\hline
\end{tabular}

$1 \%$ RSD values for ICP-MS and chromium by GF-AAS are experimental only. All other \%RSD values were calculated from historical data or regression curves on the basis of Standard Reference Water Samples that were submitted to those instrumental techniques over a 2-year period.

${ }^{2}$ R.L. for ICP is for samples with specific conductance less than $2,000 \mu \mathrm{S} / \mathrm{cm}$. 


\section{GF-AAS--Graphite Furnace Atomic Absorption Spectrophotometry}

While this technique uses a form of atomic absorption and is only used to determine one analyte at a time, it generally has a much lower reporting limit than conventional AAS. On an element-byelement basis, GF-AAS is the most expensive of the analytical methods. The primary difference between AAS and GF-AAS is the method of introducing a sample into the light path. GF-AAS uses pyrolysis and chemical matrix modifiers to reduce interferences from other elements that might be present in the sample. This is one of the newer techniques currently (1994) under routine use for the determination of metals, and generally has a reporting limit lower than that of the ICP. GF-AAS is most effective when lower reporting limits are required for a fewer number of analytes. (See table 1 for comparison of techniques.)

\section{ICP--Inductively Coupled Plasma}

This is an atomic emission spectrometric technique that is used to simultaneously determine up to 20 analytes. It is a multielement test that uses a high-temperature plasma as a sample introduction device; emission is simultaneously read at different wavelengths inside the instrument. Assuming that very low detection levels are not required, ICP usually is the most cost-effective method for obtaining data on several different analytes. This technique is well suited for analysis of relatively clean, filtered samples whose specific conductance is less than $2,000 \mu \mathrm{S} / \mathrm{cm}$. (See table 1 for comparison of techniques.)

\section{ICP-MS--Inductively Coupled Plasma-Mass Spectrometry}

This technique uses the high-temperature plasma as a sample-introduction device for the mass spectrometer. Currently (1994), this multielement technique is expected to be used for low-level studies and blank water testing. This method will not work for iron determinations because of spectral interferences, but it may be a more cost-effective method than GF-AAS when considering a number of elements in the microgram-per-liter range. ICP-MS has been developed for samples with specific conductance less than $2,500 \mu \mathrm{S} / \mathrm{cm}$. (See table 1 for comparison of techniques.)

The precision of various regular-level methods at their published reporting limits is listed in table 1. Percent Relative Standard Deviation (\%RSD) values listed are based on replicate analysis of standards or reference materials at the method reporting limit. More information concerning the precision of each analytical instrument is available at the NWQL or can be obtained in reports periodically distributed by the Branch of Quality Assurance (BQA).

\section{Low-Ionic Strength Methods}

The NWQL offers a series of low-ionic strength methods that can provide reduced reporting limits at substantially greater costs. These methods are intended for clean samples whose specific conductance is less than $100 \mu \mathrm{s} / \mathrm{cm}$, or water where the constituent levels are expected to be less than the reporting limits available using routine analytical methods. The majority of the low-ionic strength analyses determine analytes at or slightly greater than the reporting limit, and might be desirable when a project's data-quality objectives require greater precision at the low end than is commonly available when using routine analytical methods. Care needs to be used when requesting these methods; if the analyte concentrations exceed the ranges available for low-ionic strength methods, both precision and accuracy will be adversely affected by dilution procedures required to bring these samples into range. 


\section{Organic Chemistry Program}

The Organic Chemistry Program offers analyses for organic compounds such as insecticides, herbicides, and base neutral acids in water, bed sediment, and tissue samples. While inorganic analyses are often determined and reported by individual analyte, organic compounds are determined and reported in groups of constituents. The constituent grouping is based on shared chemical properties that allow organic compounds to be separated from other groups and determined using a single analytical procedure. Organic analytical procedures are typically set up by schedules. For more information on reporting limits or specific constituent lists for each schedule, refer to either the NWQL Services Catalog (Watterson and Kashuba, 1993) or the SPN program on the PRIME.

Because of the wide range of compounds and data transmitted for organic schedules, there may be some questions concerning the interpretation of data. Organic Chemistry Program personnel are available to help districts and cooperators in whatever manner may be required. For additional information or advice, contact the Organic Chemistry Program Chief.

\section{Organochlorine Pesticides in Water}

SCH 1608--Requires a whole-water sample and has been developed expressly for NPDES testing. The reporting level for this schedule generally is quite high, but because of USEPA NPDES requirements, this is the recommended schedule for all districts involved in NPDES permitting applications. USEPA method 608 is used for this analysis.

SCH 1324--Requires a whole-water sample. This is the most commonly used schedule for the determination of organochlorine pesticides in whole-water samples. This schedule does not use an approved USEPA method.

SCH 1398--Requires a whole-water sample, and is a low-level method that is capable of detecting organochlorine pesticides at levels less than those in the other schedules. Because it is low level, only samples with a relatively clean matrix should be submitted. This schedule requires special sample handling, and as such is substantially more expensive that SCH 1608 or 1324.

SCH 1321, 1399, 1334--Requires a filtered sample, and are only used for dissolved analytes. The applicability of these schedules should be verified with the NWQL prior to sampling.

\section{Organophosphorus Pesticides}

SCH 1319--Requires a whole-water sample and is commonly used to determine organophosphorus compounds in water.

SCH 1320--Requires a bed-sediment sample. This schedule is used to determine organophosphorus pesticides in sediments.

\section{Base Neutral Acids}

SCH 1383 and 1385--Require whole-water samples and are both for the determination of base neutral acids (BNA's) in whole water. Schedule 1385 is the same as 1383, except it also provides a library search of unknown compounds. 
SCH 1384 and 1386--Require bed-sediment samples and are both for the determination of BNA's in bed sediments. Schedule 1386 is the same as 1384 , except it also provides a library search of unknown compounds.

\section{Triazine Herbicides}

SCH 1389--Requires a whole-water sample. This is the most often requested schedule for the determination of triazine herbicides. It tests for a large number of nitrogen-containing compounds and has been widely used since 1988 .

SCH 1379--Requires a filtered sample. This schedule is for dissolved analytes and may not be used for whole-water samples. The analytes offered in this schedule are a limited subset of those offered in schedule 1389.

\section{Volatile Organic Compounds}

SCH 1380--Requires a whole-water sample. This schedule is the most commonly requested schedule for the determination of volatile organic compounds (VOC's) and includes over 60 organic compounds.

SCH 1390--Requires a whole-water sample. This schedule contains basically the same analyte list that is offered in schedule 1380, except the reporting limits are higher, and, therefore, it is offered at a reduced cost when compared to schedule 1380.

SCH 1392--Requires a whole-water sample. This schedule contains the same analyte list as schedule 1380 and also offers a library search for tentative identification of unknown compounds.

\section{Schedules Developed for National Water-Quality Assessment (NAWQA) Program}

The following schedules were developed in 1992 at the NWQL as a result of demand from the NAWQA program for more sophisticated methods of collecting and determining organic constituents in water, bed-sediment, and tissue samples. Although these schedules are owned by NAWQA, they are available for use throughout the U.S. Geological Survey. For additional information on sample collection or method selection, contact the Methods Research and Development Program at the NWQL.

SCH 2001, 2010--Provide determination of pesticides in water using solid-phase extraction (SPE) and GC/MS. The analyte list includes some of the compounds offered in schedules 1319, 1324, 1379, and 1389. Schedule 2001 represents samples that are sent to the NWQL and extracted at the laboratory using SPE, while schedule 2010 is for samples that are sent to the NWQL following field extraction using SPE techniques.

SCH 2050, 2051-- Provide determination of dissolved carbamate pesticides and phenoxyacid herbicides in water using SPE. These schedules are more cost-effective than the schedule combination of 1359 and 0079 that is currently used by many districts, and offers many of the same compounds that are included in the two schedules. Schedule 2050 represents samples that are sent to the NWQL and extracted at the laboratory, while schedule 2051 is for samples that are sent to the NWQL following field extraction using SPE techniques. 
SCH 2101--Provides determination of organochlorine pesticides in tissue. This method has been specifically developed for tissue analysis.

SCH 2501--Provides improved determination of organochlorine pesticides in bed sediments. This schedule provides both reduced detection limits and an expanded constituent list when compared to schedule 1325.

SCH 2502--Provides improved determination of BNA's in bed sediments. This schedule provides both lower detection limits and an expanded constituent list in comparison to schedule 1384 .

Schedules used in the Organic Chemistry Program are compared in table 2. For more information on available analyses or method selection, contact the Organic Program Chief.

\section{Table 2.--Summary of organic schedules}

[OC, Organochlorine; OP, Organophosphorus; BNA, Base Neutral Acid; VOC, Volatile Organic Compound; NAWQA, National Water-Quality Assessment Program; GC/MS, Gas Chromatography/Mass Spectrometry; HPLC, High-Performance Liquid Chromatography; SPE, Solid-Phase Extraction]

\begin{tabular}{|c|c|c|c|}
\hline $\begin{array}{l}\text { Schedule } \\
\text { number }\end{array}$ & $\begin{array}{l}\text { Type of } \\
\text { analysis }\end{array}$ & $\begin{array}{l}\text { Sample } \\
\text { type }\end{array}$ & $\begin{array}{l}\text { Number of } \\
\text { analytes }\end{array}$ \\
\hline $\begin{array}{l}1608 \\
1324 \\
1398\end{array}$ & $\begin{array}{l}\mathrm{OC} \\
\mathrm{OC} \\
\mathrm{OC}\end{array}$ & $\begin{array}{l}\text { Whole water } \\
\text { Whole water } \\
\text { Whole water }\end{array}$ & $\begin{array}{l}27 \\
17 \\
17\end{array}$ \\
\hline $\begin{array}{l}1321 \\
1399 \\
1334\end{array}$ & $\begin{array}{l}\mathrm{OC} \\
\mathrm{OC} \\
\mathrm{OC}\end{array}$ & $\begin{array}{l}\text { Dissolved } \\
\text { Dissolved } \\
\text { Dissolved }\end{array}$ & $\begin{array}{l}17 \\
23 \\
28\end{array}$ \\
\hline $\begin{array}{l}1319 \\
1320\end{array}$ & $\begin{array}{l}\text { OP } \\
\text { OP }\end{array}$ & $\begin{array}{l}\text { Whole water } \\
\text { Sediment }\end{array}$ & $\begin{array}{r}11 \\
6\end{array}$ \\
\hline $\begin{array}{l}1383 \\
1385\end{array}$ & $\begin{array}{l}\text { BNA } \\
\text { BNA + library search }\end{array}$ & $\begin{array}{l}\text { Whole water } \\
\text { Whole water }\end{array}$ & $\begin{array}{l}57 \\
57+\text { search }\end{array}$ \\
\hline $\begin{array}{l}1384 \\
1386\end{array}$ & $\begin{array}{l}\text { BNA } \\
\text { BNA + library search }\end{array}$ & $\begin{array}{l}\text { Sediment } \\
\text { Sediment }\end{array}$ & $\begin{array}{l}54 \\
54+\text { search }\end{array}$ \\
\hline $\begin{array}{l}1389 \\
1379\end{array}$ & $\begin{array}{l}\text { Triazine herbicides } \\
\text { Triazine herbicides }\end{array}$ & $\begin{array}{l}\text { Whole water } \\
\text { Whole water }\end{array}$ & $\begin{array}{l}24 \\
11\end{array}$ \\
\hline $\begin{array}{l}1380 \\
1390 \\
1392\end{array}$ & $\begin{array}{l}\text { VOC } \\
\text { VOC ( higher reporting limits) } \\
\text { VOC + library search }\end{array}$ & $\begin{array}{l}\text { Whole water } \\
\text { Whole water } \\
\text { Whole water }\end{array}$ & $\begin{array}{l}63 \\
63 \\
63+\text { search }\end{array}$ \\
\hline $\begin{array}{l}2001 / 2010 \\
2050 / 2051 \\
2101 \\
2501 \\
2502\end{array}$ & $\begin{array}{l}\text { NAWQA pesticides (GC/MS) } \\
\text { NAWQA pesticides (HPLC) } \\
\text { NAWQA OC } \\
\text { NAWQA OC } \\
\text { NAWQA BNA }\end{array}$ & $\begin{array}{l}\text { SPE cartridge } \\
\text { SPE cartridge } \\
\text { Tissue } \\
\text { Sediment } \\
\text { Sediment }\end{array}$ & $\begin{array}{l}50 \\
41 \\
29 \\
40 \\
77\end{array}$ \\
\hline
\end{tabular}




\section{Organic Nomenclature}

Insecticides, fungicides, and herbicides are sold commercially under different trade names, and it is not uncommon for the same compound to be known by a variety of names. For more complete information on naming, refer to the Agrochemicals Handbook (Royal Society of Chemistry, 1992) or the Farm Chemicals Handbook (Meister Publishing Company, 1993). If there are any chemicals or compounds that require determination, but do not seem to be tested for at the NWQL, please contact the laboratory to clarify the chemical name and to ensure that required services are available at the NWQL.

\section{OPTIMIZING SERVICES AND FUNDING}

When using the analytical services provided at the NWQL, it may be helpful to evaluate each project's specific needs, data-quality objectives, and available funding. In many cases, services can be maximized at a reasonable cost, providing that the schedule requests, sample types, and required delivery dates are planned in advance.

The busiest season for the NWQL corresponds with the end of the water year--August through October. For those districts that have the flexibility, sample turn-around times will be the shortest between January and March, since that is the slowest time of the year.

The selection of schedules and labcodes needs to be based on the specific objectives for any given project. By grouping projects into three broad categories--reconnaissance, assessment, and research--it is possible to generalize as to the types of services that may be most appropriate, as follows:

Reconnaissance is a broad look at a specific site to develop baseline or preliminary data. For this type of work, multielement scans such as the ICP or ICP-MS generally are the most costeffective method of obtaining data. If, however, the study requires detection limits lower than those available with ICP, or there are unusual sample characteristics to consider (for example, acid-mine drainage), then methods need to be selected on the basis of those requirements.

Assessment may involve regulatory or compliance work. Some of these projects (such as NPDES) might require specific methods, and in some cases the more economical ICP scan could be unacceptable to cooperators. In compliance monitoring, the newest USGS method is seldom acceptable, and more obscure methods might be required. It is suggested that all districts involved in regulatory work get prior approval from the cooperator for all USGS methods before proceeding. If possible, contact the Quality Management Program or Inorganic or Organic Program chiefs for assistance on method selection.

Research often involves specialized or custom analyses to meet project objectives. Whenever possible, the NWQL is willing to support customers who need custom analyses. In fact, in many cases, low-level methods might be suitable for many of the detection-level or contaminant studies. Whenever specialized methods or detection levels are needed, contact the program chiefs or the Methods Research and Development Program to assist in the selection or development of methods. 


\section{OBTAINING APPROVAL FOR REGULATORY TESTING}

The USGS methods and their corresponding USEPA method numbers are listed in table 3 to assist in the approval process. This information was compiled from the U.S. Environmental Protection Agency (1992) and should be helpful when verifying the acceptability of USGS methods. To ensure that NWQL data will be accepted by the permitting official, it is suggested that written approval be obtained prior to the regulatory testing and subsequent permit application phases.

While the NWQL has drinking-water certification from USEPA Region 8, this is not a guarantee that NWQL methods will be accepted by all USEPA regions nationwide. As it is currently (1994) organized, the USEPA consists of 10 separate regions, each with its own permitting and certification authority. It is suggested that all districts and cooperators involved in compliance monitoring verify the acceptability of NWQL methods prior to proceeding.

For those districts involved in the Department of Defense Environmental Contamination (DODEC) Hydrology Program, the NWQL provides oversight and interpretation for all work that is sent to the USGS-approved contracting laboratories. All of these samples are sent to contract laboratories because of the high concentrations of hazardous wastes and required quality assurance involved in DODEC work. As a general rule, DODEC samples are subject to extensive regulations, and their quality-assurance objectives are demanding and comprehensive. For more complete information on the DODEC program, contact the Quality Management Program at the NWQL. 
[USEPA, U.S. Environmental Protection Agency; USGS, U.S. Geological Survey; $\mu$ /L, micrograms per liter, mg/, milligrams per liter, GF-AAS, Graphite Fumace Atomic Absorption Spectrophotometry; AAS, Atomic Absorption Spectrophotometry; NPDES, National Pollution Discharge Elimination System]

\begin{tabular}{|c|c|c|c|c|c|c|}
\hline \multirow{2}{*}{$\begin{array}{l}\text { Compound } \\
\text { Antimony, total }\end{array}$} & \multicolumn{2}{|c|}{ Reporting limit } & \multicolumn{2}{|c|}{ USEPA approval } & \multirow{2}{*}{$\begin{array}{l}\text { USGS } \\
\text { method number } \\
\text { Use schedule } 907^{1}\end{array}$} & \multirow{2}{*}{$\begin{array}{l}\text { USEPA } \\
\text { method number } \\
204.2\end{array}$} \\
\hline & 10.0 & $\mu \mathrm{g} / \mathrm{L}$ & No & GF-AAS & & \\
\hline Arsenic, total & 1.0 & $\mu g / L$ & Yes & GF-AAS & None & 206.2 \\
\hline Beryllium, total & 10.0 & $\mu g / L$ & Yes & Flame AAS & I-3095-94 & 210.1 \\
\hline Cadmium, total & 10.0 & $\mu g / L$ & Yes & Flame AAS & I-3135-84/I-3138-84 & 213.1 \\
\hline Chromium, total & 10.0 & $\mu g / L$ & Yes & Flame AAS & I-3236-84 & 218.1 \\
\hline Copper, total & 10.0 & $\mu \mathrm{g} / \mathrm{L}$ & Yes & Flame AAS & I-3270-84/I-3271-84 & 220.1 \\
\hline Lead, total & 100.0 & $\mu g / L$ & Yes & Flame AAS & I-3399-84 & 239.1 \\
\hline Mercury, total & 0.1 & $\mu g / L$ & Yes & Cold vapor & 1.3462 .84 & 245.1 \\
\hline Nickel, total & 100.0 & $\mu g / L$ & Yes & Flame AAS & $1.3499-84$ & 249.1 \\
\hline Selenium, total & 1.0 & $\mu g / L$ & Yes & GF-AAS & None & 207.2 \\
\hline Silver, total & 0.5 & $\mu g / L$ & No & GF-AAS & Use schedule $907^{1}$ & 272.2 \\
\hline Thallium, total & 5.0 & $\mu g / L$ & No & GF-AAS & Use schedule $907^{1}$ & 279.2 \\
\hline Zinc, total & 10.0 & $\mu \mathrm{g} / \mathrm{L}$ & Yes & Flame AAS & I-3900-84 & 289.1 \\
\hline Cyanide, total & 0.01 & mg/L & No & & Use schedule $907^{1}$ & 335.3 \\
\hline Dissolved solids & 1.0 & $\mathbf{m g} / \mathbf{L}$ & Yes & Gravimetric & $1-1750-84$ & 160.1 \\
\hline Suspended solids & 1.0 & $\mathbf{m g} / \mathbf{L}$ & Yes & Gravimetric & I-3765-84 & 160.2 \\
\hline Chemical oxygen demand & 10.0 & $\mathrm{mg} / \mathrm{L}$ & Yes & Colorimetric & I.3561.84 & 410.4 \\
\hline pH & 0.1 & mg/L & Yes & Electrometric & I-1586-84 & 150.1 \\
\hline Nitrate-nitrite & 0.1 & $\mathbf{m g} / \mathbf{L}$ & Yes & Cadmium reduction & $1-4545-84$ & 353.2 \\
\hline Kjeldahl nitrogen & 0.2 & mg/L & Yes & Microkjeldahl digest & I-4515-84 & 351.2 \\
\hline Phosphorous, total & 0.01 & $\mathbf{m g} / \mathbf{L}$ & Yes & Microkjeldahl digest & $1-4610-91$ & 365.4 \\
\hline Phosphorous, dissolved & 0.01 & $\mathrm{mg} / \mathrm{L}$ & Yes & Microkjeldahl digest & $1-2310-91$ & 365.4 \\
\hline Benzene & 0.2 & $\mu g / L$ & Yes & & None & 524.2 \\
\hline Vinyl chloride & 0.2 & $\mu g / L$ & Yes & & None & 524.2 \\
\hline Carbon tetrachloride & 0.2 & $\mu g / L$ & Yes & & None & 524.2 \\
\hline P-Dichlorobenzene & 0.2 & $\mu g / L$ & Yes & & None & 524.2 \\
\hline Trichloroethylene & 0.2 & $\mu \mathrm{g} / \mathrm{L}$ & Yes & & None & 524.2 \\
\hline 1,1,1 Trichloroethane & 0.2 & $\mu g / L$ & Yes & & None & 524.2 \\
\hline 1,1 Dichloroethylene & 0.2 & $\mu g / L$ & Yes & & None & 524.2 \\
\hline 1,2 Dichloroethane & 0.2 & $\mu g / L$ & Yes & & None & 524.2 \\
\hline Bromoform & 0.2 & $\mu g / L$ & Yes & & None & 524.2 \\
\hline Bromodichloromethane & 0.2 & $\mu g / L$ & Yes & & None & 524.2 \\
\hline Chloroform & 0.2 & $\mu g / L$ & Yes & & None & 524.2 \\
\hline Chlorodibromomethane & 0.2 & $\mu g / L$ & Yes & & None & 524.2 \\
\hline Lindane & 0.01 & $\mu g / L$ & Yes & & $0-3104-83$ & 508 \\
\hline Toxaphene & 1.0 & $\mu g / L$ & Yes & & $0-3104-83$ & 508 \\
\hline Endrin & 0.01 & $\mu \mathrm{g} / \mathrm{L}$ & Yes & & $0.3104-83$ & 508 \\
\hline Methoxychlor & 0.01 & $\mu \mathrm{g} / \mathrm{L}$ & Yes & & $0-3104-83$ & 508 \\
\hline 2,4,D & 0.01 & $\mu g / L$ & Yes & & $0-3105-83$ & 515.1 \\
\hline 2,4,5-TP (Silvex) ${ }^{2}$ & 0.01 & $\mu g / L$ & Yes & & $0-3105-83$ & 515.1 \\
\hline
\end{tabular}

${ }^{1}$ Schedule 907 has been developed to provide USEPA certified methods for NPDES work. The analytical work is performed by a contract laboratory using the USEPA methods indicated.

${ }^{2}$ Use of brand and trade names in this report is for identification purposes only and does not constitute endorsement by the U.S. Geological Survey. 


\section{APPROVED METHODS AND SUGGESTIONS FOR NATIONAL POLLUTION DISCHARGE ELIMINATION SYSTEM PROGRAM}

The National Pollution Discharge Elimination System (NPDES) Program has required that a number of municipalities apply to the USEPA for discharge permits. This program is a result of the Clean Water Act, and requires that all municipalities with a population greater than 100,000 submit permit applications for municipal discharge (runoff). In many cases, municipal cooperators have contacted USGS personnel for assistance in sampling and testing urban runoff as required in the permit application. Additional information on the NPDES program and sampling protocol is available in a report by the U.S. Environmental Protection Agency (1992).

To support district and cooperator requests, the NWQL offers NPDES schedules, but all new NPDES participants still need to obtain prior approval from the permitting officials to ensure that USGS methods will be accepted. Because permitting officials and policies may vary from region to region, the NWQL strongly urges that cooperators obtain, in writing, official acceptance of USGS methods used in the following list of suggested NPDES schedules. To ensure that required protocols are followed, please indicate the samples as "NPDES" on the Analytical Services Request (ASR) form.

For those methods for which the NWQL does not have USEPA approval, the NWQL uses the services of contract laboratories. These contract laboratories use the required USEPA methods and participate in the Branch of Quality Assurance audit program.

Currently (1994), the NWQL is offering a number of schedules developed expressly for the NPDES Program with assistance from the USGS Office of Water Quality. The apparent duplication of analyses is the result of the Office of Water Quality wanting data from the method with the lowest detection limit, while USEPA regulations specify USEPA approved methods. The schedules have been set up to ensure that each requested analyte is determined by at least one method listed in the USEPA regulations (U.S. Environmental Protection Agency, 1991a, 1991b, 1991c). A few suggested NPDES schedules are listed as follows:

Schedule 1380: Volatiles

Schedule 1383: Semivolatiles

Schedule 1608: Pesticides + Diazanon

Schedule 904: Required NPDES + Common Ions

Schedule 905: Nutrient Parameters

Schedule 906: USGS Preferred + USEPA Required Parameters

Schedule 907: Contract Parameters--Metals 


\section{SAFE DRINKING WATER ACT}

To provide districts and cooperators with analytical services suitable for regulatory work, the NWQL maintains USEPA certification for a number of primary contaminants that are routinely monitored by the USEPA under the Safe Drinking Water Act. Once every 3 years, the NWQL participates in a USEPA Region 8 audit to maintain USEPA drinking-water certification. The most recent of these audits was in May 1992, and as a result, certification was suggested for the analytes listed in table 4.

When submitting drinking-water samples to the NWQL, please indicate them as such on the Analytical Services Request (ASR) form. This identification will ensure that the proper methods and sample-handling protocols are followed. Failure to mark the ASR's correctly might result in improper analyses. 
Table 4.--Methods for which the National Water Quality Laboratory has drinking-water certification in Region 8, U.S. Environmental Protection Agency

[GF-AAS, Graphite Fumace Atomic Absorption Spectrophotometry; ICP, Inductively Coupled Plasma; IC, Ion Chromatography; LC, Labcode; SCH, Schedule; GC/MS, Gas Chromatography/Mass Spectrometry; GC/ECD, Gas Chromatography/Electron Capture Detector]

\begin{tabular}{lll}
\hline \multicolumn{1}{c}{ Compound } & Method & \multicolumn{1}{c}{ Code or schedule } \\
\cline { 1 - 2 } & \multicolumn{2}{c}{ Inorganic } \\
Arsenic & GF-AAS & LC 1584 \\
Barium & ICP & SCH 1043 \\
Cadmium & ICP & SCH 1043 \\
Copper & ICP & SCH 1043 \\
Chromium & ICP & SCH 1043 \\
Fluoride & IC & LC 1573-provisional certification \\
Lead & ICP - GF-AAS & LC 1560 \\
Mercury & Cold vapor & LC 227 \\
Nitrate & Colorimetric & LC 228 \\
Nitrite & Colorimetric & LC 160 \\
Selenium & GF-AAS & LC 1585 \\
Total nitrate and nitrite & Colorimetric & LC 228
\end{tabular}

Volatile organic compounds and trihalomethanes

$\begin{array}{lll}\text { Benzene } & \text { GC/MS } & \text { SCH 1380 - to get all parameters } \\ \text { Bromoform } & \text { GC/MS } & \text { SCH 1380 - to get all parameters } \\ \text { Bromodichloromethane } & \text { GC/MS } & \text { SCH 1380 - to get all parameters } \\ \text { Carbon tetrachloride } & \text { GC/MS } & \text { SCH 1380 - to get all parameters } \\ \text { Chloroform } & \text { GC/MS } & \text { SCH 1380 - to get all parameters } \\ \text { Chlorodibromomethane } & \text { GC/MS } & \text { SCH 1380 - to get all parameters } \\ \text { p-Dichlorobenzene } & \text { GC/MS } & \text { SCH 1380 - to get all parameters } \\ \text { Trichloroethylene } & \text { GC/MS } & \text { SCH 1380 - to get all parameters } \\ \text { Vinyl chloride } & \text { GC/MS } & \text { SCH 1380 - to get all parameters } \\ \text { 1,1,1-Trichloroethane } & \text { GC/MS } & \text { SCH 1380 - to get all parameters } \\ \text { 1,1-Dichloroethylene } & \text { GC/MS } & \text { SCH 1380 - to get all parameters } \\ \text { 1,2 Dichloroethane } & \text { GC/MS } & \text { SCH 1380 - to get all parameters }\end{array}$

Organochlorine pesticides (provisional certification)

$\begin{array}{lll}\text { Endrin } & \text { GC/ECD } & \text { SCH 1324 - to get all parameters } \\ \text { Lindane } & \text { GC/ECD } & \text { SCH 1324 - to get all parameters } \\ \text { Methoxychlor } & \text { GC/ECD } & \text { SCH 1324 - to get all parameters } \\ \text { Toxaphene } & \text { GC/ECD } & \text { SCH 1324 - to get all parameters }\end{array}$

\section{Herbicides (provisional certification)}

$\begin{array}{lll}2,4-D & \text { GC/ECD } & \text { SCH } 1304 \text { - to get all parameters } \\ 2,4,5-\mathrm{TP} \text { (Silvex) } & \text { GC/ECD } & \text { SCH } 1304 \text { - to get all parameters }\end{array}$

\footnotetext{
${ }^{1}$ While the USEPA reviewing official gave certification for lead by ICP, it was recommended that a graphite furnace technique be used after January 1993
} to satisfy revised maximum contaminant levels. 


\section{HOW TO AVOID UNWANTED SWAPPING OF TEST PROCEDURES AND ENSURE DELIVERY OF ACCEPTABLE DATA}

To streamline, and, in many cases, economize on analytical costs, the NWQL uses what is commonly referred to as a "swapping routine." This program scans samples and their accompanying analytical requests to ensure that laboratory resources are being used efficiently and to protect instrumentation against unsuitable samples (for example, samples with specific conductances greater than $6,000 \mu \mathrm{S} / \mathrm{cm}$ are not suitable for ICP).

When applicable, more efficient methods might be substituted in place of those requested, thus the term "swapping." For example, customers requesting more than six trace metals, and not specifying GF-AAS methods, will automatically be "swapped" to the ICP. This policy provides districts with a more cost-effective analysis, while maximizing the efficiency of the NWQL. Also, when improper samples are submitted, the program will automatically change the analytical request to one appropriate for that sample type; in the case of low-ionic strength requests, samples whose specific conductances are greater than $100 \mu \mathrm{S} / \mathrm{cm}$ are automatically transferred to regular-level analytical lines.

Swapping generally does not pose a problem unless a district or cooperator has specific reasons for wanting a particular method used. If, however, specific methods are required, and swapping is unacceptable, place a " $Z$ " in the upper left-hand corner of the ASR. This marks the sample as one that may not be swapped, and as a result, the swapping routine is bypassed.

The "Z" code is only used in those instances where it is clearly known that swapping will cause undue confusion or result in unacceptable data. It does not guarantee that the best or most effective method will be run, but instead ensures that only those labcodes requested are run. The " $Z$ " code needs to be used carefully and should be verified with NWQL personnel prior to entry on an ASR form.

For special concerns, or limited sample volumes such as pore water, please make prior arrangements with a program chief to ensure that the proper methods are being requested, that no inappropriate methods are swapped, and that the best use is made of limited sample volumes.

\section{CONTACTING NATIONAL WATER QUALITY LABORATORY STAFF}

The staff at the NWQL is eager to provide support in whatever roles district colleagues and cooperators might deem appropriate. Clearly, there are a number of complicated issues that need to be resolved whenever analytical data are being collected or used. As is often the case, sometimes data might be ambiguous or difficult to interpret; for assistance in data interpretation, please do not hesitate to contact the NWQL for guidance or advice. The NWQL intends that the staff be available to aid in the decision-making process whenever called upon, and if additional support is required, it will be provided.

For those customers requiring rapid turnaround on samples, it may be useful to submit samples to the NWQL between January and March whenever possible. Those requiring rapid turnaround during the rest of the year may contact program chiefs to arrange for priority handling. Priority status is only offered on a limited basis, and all priority samples are assigned an additional surcharge depending on the turnaround requested and the scheduled workload. 
When in Denver, feel free to visit the NWQL and meet with the program chiefs and analysts who handle the majority of the analytical work. For an in-depth tour, contact one of the program chiefs about a week in advance; if a short visit is more appropriate, give the NWQL a day's notice to ensure that personnel are available to answer questions. The NWQL is looking forward to a more interactive and open relationship with customers in the districts and with all those who use NWQL analytical services. We hope to see or hear from you soon!

\section{REFERENCES CITED}

Meister Publishing Company, 1993, Farm chemicals handbook: Willoughby, Ohio, variable pagination.

Royal Society of Chemistry, 1992, The agrochemicals handbook: The University of Nottingham, England, variable pagination.

U.S. Environmental Protection Agency, 1991a, Primary drinking-water regulations, maximum contaminant levels (Part 136, paragraphs 136.1 through 136.3, Guidelines establishing test procedures for the analysis of pollutants): U.S. Code of Federal Regulations, Title 40, parts 100149 , revised as of July 1,1991 , p. 293-310

1991b, Primary drinking-water regulations, maximum contaminant levels (subpart B of part 141, National secondary drinking-water regulations): U.S. Code of Federal Regulations, Title 40, parts 100-149, revised as of July 1, 1991, p. 585-588

1991c, Primary drinking-water regulations, maximum contaminant levels (subpart C of part 141, National secondary drinking-water regulations): U.S. Code of Federal Regulations, Title 40, parts $100-149$, revised as of July 1,1991 , p. 588-646

1992, NPDES storm water sampling guidance document: Washington, D.C., U.S. Environmental Protection Agency, EPA 833-B-92-001, variable pagination.

Watterson, C.A., and Kashuba, A.T., 1993, 1993 National Water Quality Laboratory services catalog:

U.S. Geological Survey, Technical Memorandum 93.04, 115 p. (available by contacting the National Water Quality Laboratory). 